\title{
The Comparative Analysis of Maternal Mortality in the Russian Federation and Chechen Republic for the Period of 2010-2017
}

\author{
Khachuraeva M.M.* Akhmadova P.G. \\ Fifth-year student, Medical faculty, Medical Institute, Chechen State University, Grozny, Russia \\ *Corresponding author.Email: makka.khachuraeva@mail.ru,akhmadovapetimat@mail.ru
}

\begin{abstract}
The article presents a comparative analysis of the dynamics of maternal mortality (MM) and its structure in the Russian Federation and the Chechen Republic for the period 2010-2017. In the Russian Federation for the period 2010-2017, there was a persistent decrease in maternal mortality by $6.7 \%$. While in 2010, the maternal mortality rate in the RF was $16.5 \%$, the indicator in 2017 was $9.8 \%$. It turned out that the maternal mortality rate in the Chechen Republic for the period from 2010 to 2017 tends to decrease by $32.6 \%$, but this indicator exceeds the average statistical indicator of maternal mortality in the RF (6.7\%). In the structure of MM since 2010 in the Russian Federation, the leading causes of maternal mortality are: complications of pregnancy against the background of severe extragenital pathology, bleeding, gestosis, amniotic fluid embolism. The leading cause of maternal mortality in the Chechen Republic is bleeding, apparently, this is due to: untimely access of pregnant women for medical care, doctors ignoring the clinical recommendations of the Ministry of Health of the Russian Federation, insufficient technical equipment of medical institutions of I and II levels, ineffective interaction among doctors of antenatal clinics and doctors of obstetric hospitals of I, II and III levels, lack of operational skills among doctors of obstetric hospitals. In second place are complications of severe extragenital pathology. Apparently, one of the reasons for the increase in maternal mortality in the republic is the low health index of women of childbearing age, which leads to an increase in the number of pregnancies and childbirth occurring against the background of severe extragenital pathology.
\end{abstract}

Keywords: maternal mortality, dynamics and structure of maternal mortality, Russian Federation, Chechen Republic

\section{INTRODUCTION}

Maternal mortality (MM) is a statistical indicator that is an indicator of the reproductive and somatic health of the female population. MM characterizes not only the quality of obstetric and gynecological care during pregnancy, childbirth, the postpartum period, the adequacy of medical care in life-threatening situations in this category of women, but is also a criterion for assessing the effectiveness of the functioning of the health care system on a global scale [WHO, 2016].

The urgency of the problem of maternal mortality (MM) in the Chechen Republic is currently very high [3]. Despite the decrease in maternal mortality from 52.6 in 2010 to 20.0 per 100 thousand births. alive. in 2017 , this indicator remains high and reaches the level of priority tasks of the republic's health care [4].

Maternal mortality has not only medical, but social and economic significance [1]. The index most fully reflects the population outcome, all aspects of the country's social life, and most importantly the level of adequacy and efficiency of the health care system [1].
Goal of the work: to study and compare the frequency and structure of maternal mortality in the Russian Federation and the Chechen Republic for the period 2010 2017.

\section{MATERIALS}

When analyzing MM in the Russian Federation (RF) and the Chechen Republic (Chechen Republic), the data and materials of the annual reports of the Ministry of Health of the Chechen Republic (forms No. 13 and 32) for the period 2010-2017 were used.

\section{RESULTS AND DISCUSSION}

In general, in the Russian Federation, there is a persistent trend towards a decrease in MM, which is due to the improvement in the provision of medical care to pregnant women, postpartum women and women in labor. The Chechen Republic is no exception. For the period from 2010 to 2017 in the Chechen Republic, a decrease in the maternal mortality rate by $32.6 \%$ was revealed (Figure 1 ), 
while in the Russian Federation (RF), the maternal mortality tends to a persistent decrease by 6.7 [4]

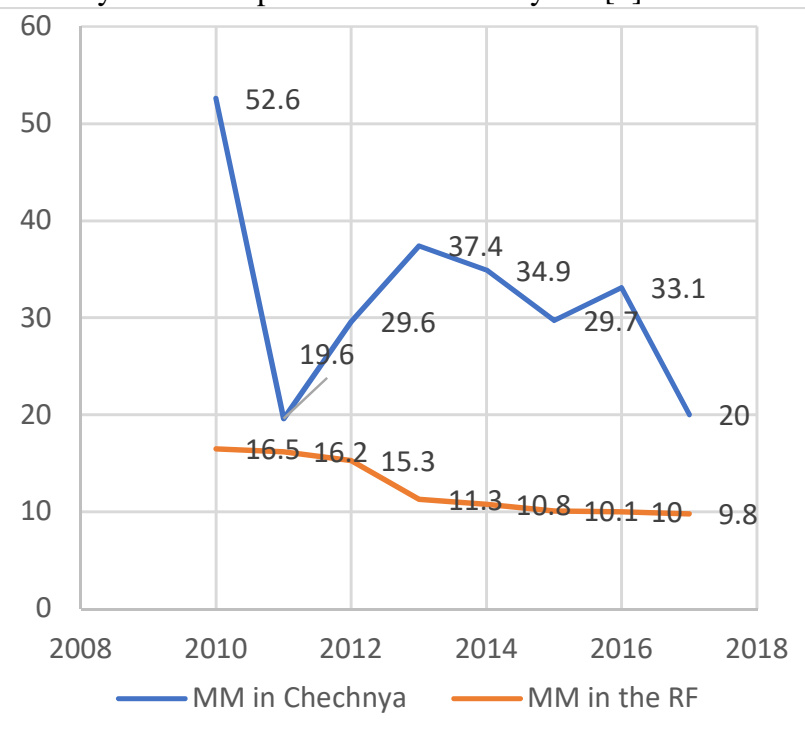

Figure 1 Dynamics of changes in the indicator of maternal mortality in the Chechen Republic and the Russian Federation (per 100,000 births)

In 2011 to 2013 in the Czech Republic, there was an increase in the percentage of maternal mortality (17.8\%). The lowest maternal mortality rate was in 2011 (19.6\%). In the Russian Federation for the period 2010-2017, there was a persistent decrease in maternal mortality by $10.9 \%$. While in 2010, the maternal mortality rate in the Russian Federation was $16.5 \%$, the indicator in 2017 was $9.8 \%$. It turned out that the maternal mortality rate in the Chechen

Table 1 Structure of the causes of maternal mortality in the Chechen Republic for the period from 2010 to 2017
Republic for the period from 2010 to 201. tends to decrease by $32.6 \%$, but this indicator exceeds the average statistical indicator of maternal mortality in the Russian Federation $(6.7 \%)$.

Based on a comparative analysis of the structure of the causes of maternal mortality in the Chechen Republic and the Russian Federation, it was revealed that in the Russian Federation the leading causes of maternal mortality are: in the first place are pregnancy complications against the background of severe extragenital pathology (27.4\%), followed by bleeding (17.4\%), gestosis (12.2\%), amniotic fluid embolism (12.7\%).

The leading cause of maternal mortality in the Chechen Republic is bleeding (22.6\%), apparently this is due to: untimely access of pregnant women for medical care, doctors ignoring the clinical recommendations of the Ministry of Health of the Russian Federation [2], insufficient technical equipment of medical institutions of I and II levels, ineffective interaction among doctors of antenatal clinics and doctors of obstetric hospitals of I, II and III levels, lack of operational skills among doctors of obstetric hospitals.

Complications of severe extragenital pathology are ranked second among the causes of maternal mortality in the Chechen Republic. Apparently, one of the reasons for the increase in maternal mortality in the republic is the low health index of women of childbearing age [3], which leads to an increase in the incidence of pregnancy and childbirth occurring against the background of severe extragenital pathology.

The leading causes of maternal mortality in the Chechen Republic for the period from 2010-2017 also are: PATE $(18.3 \%)$, sepsis $(18.3 \%)$ and gestosis $(11.8 \%)$.

\begin{tabular}{|c|c|c|c|c|c|c|c|c|c|}
\hline Reasons for MM & $\begin{array}{c}2010 \\
\text { abs.v. } \\
(\%)\end{array}$ & $\begin{array}{c}2011 \\
\text { abs.v. } \\
(\%)\end{array}$ & $\begin{array}{c}2012 \\
\text { abs.v. } \\
(\%)\end{array}$ & $\begin{array}{c}2013 \\
\text { abs.v. } \\
(\%)\end{array}$ & $\begin{array}{c}2014 \\
\text { abs.v. } \\
(\%)\end{array}$ & $\begin{array}{c}2015 \\
\text { abs.v. } \\
(\%)\end{array}$ & $\begin{array}{c}2016 \\
\text { abs.v. } \\
(\%)\end{array}$ & $\begin{array}{c}2017 \\
\text { abs.v. } \\
(\%)\end{array}$ & $\begin{array}{c}\text { Total, } \\
\text { abs.v. } \\
(\%)\end{array}$ \\
\hline Bleeding & $6(33.3)$ & - & $1(4.8)$ & $3(14.3)$ & $3(14.3)$ & $2(9.5)$ & $4(19.0)$ & $2(9.5)$ & $21(22.6)$ \\
\hline Gestosis & $1(5.5)$ & $2(18.2)$ & - & - & $3(27.2)$ & & $4(36.4)$ & $1(9.0)$ & $11(11.8)$ \\
\hline Sepsis & $1(5.5)$ & $1(14.3)$ & $4(40.0)$ & $5(41.7)$ & $1(9.0)$ & $2(22.0)$ & $2(10.0)$ & $1(16.7)$ & $17(18.3)$ \\
\hline Rupture of the uterus & $1(5.5)$ & - & $1(10.0)$ & - & - & - & - & - & $2(2.1)$ \\
\hline Complication of anesthesia & $2(11.1)$ & - & - & $1(4.5)$ & - & - & - & - & $3(3.2)$ \\
\hline AFE & $1(5.5)$ & $1(14.3)$ & - & $1(4.5)$ & $2(18.1)$ & $1(11)$ & - & $2(33.3)$ & $8(8.6)$ \\
\hline PATE & $2(11.1)$ & $1(14.3)$ & $4(40.0)$ & $2(9.0)$ & - & $2(22.0)$ & $6(30.0)$ & - & $17(18.3)$ \\
\hline Other reasons & - & - & - & - & - & $2(22.0)$ & - & - & $2(2.1)$ \\
\hline Extragenital pathology & $4(22.2)$ & $2(28.5)$ & - & & $2(18.1)$ & - & $4(20.0)$ & - & $12(12.9)$ \\
\hline Total & & & & & & & & & 93 \\
\hline
\end{tabular}


Table 2 Structure of the causes of maternal mortality in the Russian Federation for the period from 2010 to 2017

\begin{tabular}{|c|c|c|c|c|c|c|c|c|c|}
\hline $\begin{array}{c}\text { Reasons for } \\
\text { MM }\end{array}$ & $\begin{array}{c}2010 \\
\text { abs.v. } \\
(\%)\end{array}$ & $\begin{array}{c}2011 \\
\text { abs.v. } \\
(\%)\end{array}$ & $\begin{array}{c}2012 \\
\text { abs.v. }(\%)\end{array}$ & $\begin{array}{c}2013 \\
\text { abs.v. }(\%)\end{array}$ & $\begin{array}{c}2014 \\
\text { abs.v. } \\
(\%)\end{array}$ & $\begin{array}{c}2015 \\
\text { abs.v. } \\
(\%)\end{array}$ & $\begin{array}{c}2016 \\
\text { abs.v. }(\%)\end{array}$ & $\begin{array}{c}2017 \\
\text { abs.v. } \\
(\%)\end{array}$ & $\begin{array}{c}\text { Total, } \\
\text { abs.v. } \\
.(\%)\end{array}$ \\
\hline Bleeding & $62(18.8)$ & $38(16.3)$ & $40(20.0)$ & $42(20.0)$ & $34(20.8)$ & $29(16.3)$ & $24(13.8)$ & $18(13.6)$ & $287(17.4)$ \\
\hline Gestosis & $36(10.9)$ & $27(11.6)$ & $22(11.0)$ & 25 (11.9) & $33(20.2)$ & $20(11.2)$ & $22(12.6)$ & $16(12.1)$ & $201(12.2)$ \\
\hline Sepsis & $32(9.7)$ & $19(8.2)$ & $4(2.0)$ & $11(5.2)$ & $7(4.3)$ & $7(3.9)$ & $13(7.5)$ & $8(6.1)$ & $103(6.5)$ \\
\hline $\begin{array}{l}\text { Rupture of } \\
\text { the uterus }\end{array}$ & $11(3.3)$ & $7(3.1)$ & $1(0.5)$ & $8(3.8)$ & $5(3.1)$ & $4(2.2)$ & $2(1.1)$ & $3(2.3)$ & $68(4.1)$ \\
\hline $\begin{array}{l}\text { Complication } \\
\text { of anesthesia }\end{array}$ & $19(5.7)$ & $12(5.2)$ & $8(4.0)$ & $6(2.8)$ & $5(3.1)$ & $6(3.4)$ & $4(2.3)$ & $5(3.8)$ & $65(3.9)$ \\
\hline AFE & $29(8.8)$ & $21(9.1)$ & $28(14.0)$ & $34(16.2)$ & $24(14.7)$ & $22(12.3)$ & $32(18.4)$ & $20(15.1)$ & $210(12.7)$ \\
\hline PATE & $15(4.5)$ & $11(4.7)$ & $9(4.5)$ & $12(5.7)$ & $6(3.7)$ & $8(4.5)$ & $5(2.9)$ & $6(4.5)$ & $72(4.4)$ \\
\hline Other reasons & $5(1.5)$ & $25(10.8)$ & $37(18.5)$ & $25(11.9)$ & $27(16.6)$ & $27(15.2)$ & $23(13.2)$ & $21(15.9)$ & $190(11.5)$ \\
\hline $\begin{array}{l}\text { Extragenital } \\
\text { pathology }\end{array}$ & $121(36.6)$ & $72(31.0)$ & $51(25.5)$ & $47(22.3)$ & $22(13.5)$ & $55(30.9)$ & $49(28.2)$ & $35(26.5)$ & $452(27.4)$ \\
\hline Total & & & & & & & & & 1648 \\
\hline
\end{tabular}

\section{CONCLUSION}

In the Russian Federation for the period from 2010 to 2017. there was a persistent decrease in the maternal mortality rate, which is apparently associated with an improvement in the provision of medical care to pregnant women, postpartum women and women in labor.

According to the results of the analysis of maternal mortality, the leading causes of maternal mortality in the Chechen Republic are bleeding, compared to the Russian Federation, where accompanying extragenital pathology is in the first place.

Thus, indicators of maternal mortality in the Chechen Republic for the period from 2010 to 2017 has a tendency to decrease (in 2017 it was $20.0 \%$ ), but exceeds the average statistical indicator for 2017 in the Russian Federation $(9.8 \%)$.

\section{REFERENCES}

[1] V.I. Kulakov, Ways to reduce maternal mortality in Russia 2 (2014) 3-6.

[2] Obstetric bleeding, Clinical recommendations, 2016, pp. 7-8.
[3] Key indicators of the obstetric and gynecological service in the Chechen Republic in 2017, Directory, pp. 29-33.

[4] Key performance indicators of the obstetric and gynecological service in the Russian Federation in 2017, Directory, pp. 23-25.

[5] Health Protection of Mothers and Children 2003, Materials of the 5th Russian Scientific Forum, ed. by V.I. Kulakov, V.N. Serov, Yu.I. Barashnev, Aviaizdat, Moscow, 2003.

[6] G.K. Oksenoit, S.Yu Nikitina, Demographic Yearbook of Russia, Rosstat, Moscow, 2017, 263 p.

[7] L.P. Tarasova, Maternal mortality is a global scourge of humanity, in: Topical issues of reproductive health protection of the population, Publ. house of MI OSU n.a. Turgenev, Oryol, 2007, 312-317.

[8] V.I. Starodubov, L.P. Sukhanova, Reproductive Problems of Demographic Development in Russia, Health Manager, Moscow, 2012, 320 p.

[9] E.V. Fakhrutdinova, R.Kh. Yagudin, The quality of life of the population and the demographic situation: the dialectic of interaction, Econ. Sci. 12(85) (2011) 88-93.

[10] V.E. Radzinsky Obstetric aggression, Media Bureau Status Presence, Moscow, 2011, 688 p. 